\title{
PENGGUNAAN CITRA MODIS SEBAGAI PENDUGA SUHU DALAM PERHITUNGAN EVAPOTRANSPIRASI DENGAN METODE BLANEY-CRIDDLE (STUDI KASUS: DAS CIMADUR, BANTEN)
}

\section{The use of Modis Image for Temperature Estimation in Evapotranspiration Calculation with Blaney-Criddle Method (Case Study: Cimadur Watershed, Banten)}

\section{Reyna Prachmayandini1), Suria Darma Tarigan2) ${ }^{*}$, dan Bambang H. Trisasongko2)}

1) Alumni Program Studi Manajemen Sumberdaya Lahan Fakultas Pertanian IPB, J1. Meranti Kampus IPB Darmaga, Bogor 16680

2) Departemen Ilmu Tanah dan Sumber Daya Lahan, Fakultas Pertanian IPB, Jl. Meranti Kampus IPB Darmaga, Bogor 16680

\begin{abstract}
Evapotranspiration (ET) is the most important component of water balance after precipitation. Currently, evapotranspiration can be estimated using remote sensing. This research empirical equation of evapotranspiration namely the Blaney-Criddle, by utilizing value of Land Surface Temperature (LST) which was extracted from Moderate Resolution Imaging Spectroradiometer (MODIS), as a temperature input in this equation. The validation was conducted between the value of LST MODIS (acquisition day and night) and value of T of Darmaga Climatology Station at various heights $(5 \mathrm{~cm}, 100 \mathrm{~cm}, 120 \mathrm{~cm})$ and times (07.00, 07.10, 13.00 and 13.50 WIB). On LST day, temperature estimated by MODIS, had good correlation to the temperature measurement on climatology station at a height $5 \mathrm{~cm}$ (compared to temperature measurements at the other height), with a $R^{2}$ value 0.36. While the LST night have a fairly strong relationship with the T station at a height $120 \mathrm{~cm}$. However, the highest $R^{2}$ values obtained on the relationship between LST night with the T station at a height of $100 \mathrm{~cm}$ with a $R^{2}$ value of 0.57. Generally, the evapotranspiration potential value in Cimadur watershed were in the range of 4.45-5.65 mm day $^{-1}$ (close to the actual condition). Remote sensing data and evapotranspiration value could be presented spatially and temporally. However, there were constraints related to the availability of data because the evapotranspiration value was only available in the dry months. This study showed that if this condition is combined with the best of LST within a month, the availability of data of spatially and temporally potential evapotranspiration in one month could be be increased more than $50 \%$ from the initial condition $0 \%$.
\end{abstract}

Keywords : Blaney-Criddle, Cimadur Watershed, evapotranspiration, LST MODIS

\begin{abstract}
ABSTRAK
Evapotranspirasi (ET) merupakan komponen neraca air terpenting setelah curah hujan. Saat ini, pengukuran evapotranspirasi dapat dilakukan dengan menggunakan input data yang berbasis penginderaan jauh. Penelitian ini mengembangkan rumus empirik perhitungan evapotranspirasi, yaitu Blaney-Criddle, dengan memanfaatkan nilai Land Surface Temperature (LST) yang diekstrak melalui citra Moderate Resolution Imaging Spectroradiometer (MODIS) sebagai masukan dalam komponen suhu dalam persamaan tersebut. Validasi dilakukan antara nilai LST MODIS (akuisisi siang dan malam) dan nilai T Stasiun Iklim Darmaga, pada berbagai ketinggian $(5 \mathrm{~cm}, 100 \mathrm{~cm}, 120 \mathrm{~cm})$ dan waktu $(07.00,07.10,13.00$, dan 13.50 WIB). Pada LST siang, temperatur yang diestimasi oleh MODIS, lebih mendekati pengukuran temperatur stasiun iklim pada ketinggian $5 \mathrm{~cm}$ (dibandingkan dengan pengukuran temperatur pada ketinggian lainnya) dengan nilai $\mathrm{R}^{2}$ sebesar 0.36 . Sedangkan LST malam, memiliki hubungan yang cukup kuat dengan T stasiun pada ketinggian $120 \mathrm{~cm}$. Namun demikian, nilai $\mathrm{R}^{2}$ tertinggi didapatkan pada hubungan antara LST malam dengan $\mathrm{T}$ stasiun pada ketinggian $100 \mathrm{~cm}$, dengan nilai $\mathrm{R}^{2}$ sebesar 0.57. Secara umum, nilai evapotranspirasi potensial yang berada pada DAS Cimadur berada pada rentang 4.45-5.65 $\mathrm{mm}$ hari $^{-1}$ (mendekati kondisi sebenarnya). Dengan berbasis penginderaan jauh, nilai evapotranspirasi dapat disajikan secara spasial maupun temporal. Namun demikian, terdapat kendala terkait ketersediaan data yang menyebabkan nilai evapotranspirasi hanya tersedia pada bulan-bulan kering. Penelitian ini menunjukkan bahwa jika hal ini diperbaiki dengan mengkombinasikan data LST terbaik dalam 1 bulan, ketersediaan data evapotranspirasi potensial secara spasial dan temporal dalam satu bulan dapat meningkat $>50 \%$ dari kondisi awal $0 \%$.
\end{abstract}

Kata kunci : Blaney-Criddle, DAS Cimadur, evapotranspirasi, LST MODIS 


\section{PENDAHULUAN}

Dalam siklus hidrologi, evapotranspirasi merupakan komponen neraca air terpenting setelah curah hujan. Evapotranspirasi merupakan jumlah air total yang dikembalikan lagi ke atmosfer dari permukaan tanah, badan air, dan vegetasi oleh adanya pengaruh faktor-faktor iklim dan fisiologis vegetasi (Asdak, 2010). Pengetahuan mengenai evapotranspirasi penting dalam manajemen sumberdaya air, pendugaan hasil tanaman dan dalam mempelajari hubungan antara perubahan penggunaan lahan dan iklim.

Pada perkembangannya, terdapat beberapa cara pengukuran/perhitungan evapotranspirasi (potensial) secara sederhana, misalnya dengan menggunakan panci evaporasi, atau dengan menggunakan alat ukur Lysimeter. Selain itu, terdapat beberapa persamaan empiris yang sering digunakan dalam perhitungan evapotranspirasi (aktual dan potensial), salah satunya adalah metode Blaney-Criddle.

Pada metode Blaney-Criddle, besarnya suhu dan panjang hari (lama waktu penyinaran matahari) merupakan suatu masukan utama. Wang et al. (2007) menjelaskan bahwa metode Blaney-Criddle merupakan salah satu metode empiris yang tergolong sederhana dan memiliki akurasi yang cukup baik, serta membutuhkan sedikit data masukan.

Data suhu sebagai masukan utama, bisa didapatkan di stasiun meteorologi dan klimatologi. Data kemudian dikumpulkan sebagai titik-titik contoh dengan distribusi yang jarang menjangkau wilayah dengan kondisi iklim yang bervariasi (Vancutsem et al., 2010). Untuk mengatasi kekurangan tersebut, metode interpolasi seringkali dikembangkan. Namun, metode interpolasi biasanya membutuhkan banyak data stasiun.

Saat ini, kebutuhan akan informasi suhu secara spasial dengan akses data yang mudah, dapat dibangun dengan metode yang berbasis remote sensing, salah satunya dengan menggunakan citra MODIS (Moderate Resolution Imaging Spectroradiometer). Citra MODIS merupakan sensor yang dibawa oleh satelit Terra dan Aqua, yang diluncurkan pada tahun 1999 dan 2002. MOD11A2 merupakan produk Land Surface Temperature (LST) yang dibawa oleh satelit Terra (Tomlinson et al., 2011).

Penelitian ini mencoba mengembangkan metode perhitungan evapotranspirasi empirik (Blaney-Criddle) dengan menggunakan data LST MODIS sebagai masukan utama, pada wilayah dengan ketersediaan data minim. Penelitian ini bertujuan untuk: (1) mempelajari keterkaitan antara data LST MODIS dengan data T stasiun iklim pada berbagai ketinggian dan waktu pengukuran, (2) mengembangkan perhitungan evapotranspirasi dengan menggunakan LST MODIS sebagai data pendugaan suhu, (3) mengetahui kapan dan dalam kondisi apa data penginderaan jauh dapat digunakan sebagai masukan dalam perhitungan evapotranspirasi, (4) melihat pola penyebaran evapotranspirasi secara spasial dan temporal di DAS Cimadur.

\section{BAHAN DAN METODE}

\section{Bahan dan Alat}

Data yang diperlukan pada penelitian ini diperoleh dari berbagai sumber. Data utama berupa berbagai citra MODIS (MOD11A2) akuisisi data 8 harian yang diperoleh dari http://ladsweb.nascom.nasa.gov. Tabel 1 menyajikan spesifikasi data yang digunakan dalam penelitian.

Tabel 1. Data dan sumber data

\begin{tabular}{|c|c|c|}
\hline No. & Jenis Data & Sumber Data \\
\hline 1 & $\begin{array}{l}\text { Citra MODIS tahun 2008- } \\
2011\end{array}$ & http://ladsweb.nascom.nasa.gov \\
\hline 2 & $\begin{array}{l}\text { Peta Digital Rupa Bumi } \\
\text { Indonesia }\end{array}$ & Peta Rupa Bumi Bakosurtanal \\
\hline 3 & Citra Google Earth & Google Earth \\
\hline 4 & Citra ALOS AVNIR-2 & $\begin{array}{l}\text { Japan Aerospace Exploration } \\
\text { Agency (JAXA)-ALOS PP2 IPB }\end{array}$ \\
\hline 5 & $\begin{array}{l}\text { Data Temperatur Harian } \\
\text { Bogor Tahun 2008-2011 }\end{array}$ & $\begin{array}{l}\text { Stasiun Klimatologi Darmaga, } \\
\text { Bogor }\end{array}$ \\
\hline
\end{tabular}

Perangkat yang digunakan dalam penelitian ini adalah seperangkat komputer, perangkat lunak ENVI dan ArcGIS, Microsoft Word XP, dan Microsoft Excel XP.

\section{Metode Penelitian}

Tahap awal dalam penelitian ini adalah pembuatan batas wilayah DAS Cimadur menggunakan software ArcGIS, yang diturunkan dari peta kontur dijital RBI skala 1:25,000. Selanjutnya, peta penggunaan lahan DAS Cimadur dibuat berdasarkan citra tahun 2008, 2009, dan 2010 yang telah diunduh dari Google Earth dan juga ALOS AVNIR-2. Adapun klasifikasi penggunaan lahan dibedakan menjadi sawah, pemukiman, semak/tegalan, kebun campuran, hutan, dan lahan terbuka.

Analisis kemudian dilanjutkan dengan koreksi geometrik pada citra MODIS sekaligus dilakukan ekstrak data sehingga didapatkan data LST MODIS siang, dan LST MODIS malam. Kemudian, dilakukan validasi data LST MODIS untuk mengetahui bagaimana hubungan antara temperatur yang terukur pada LST MODIS dengan temperatur udara yang terukur pada stasiun klimatologi. Validasi temperatur dilakukan pada berbagai ketinggian sangkar meteo $(5 \mathrm{~cm}, 100 \mathrm{~cm}$, dan $120 \mathrm{~cm})$ dan juga pada jam pengamatan tertentu (pukul 07.00, 07.10, 13.00 dan 13.50 WIB) sejak bulan April sampai September 2011.

Selanjutnya, dilakukan perhitungan suhu rata-rata (T-mean). Perhitungan T-mean dilakukan sesuai dengan persamaan:

$$
\begin{aligned}
& \text { Tmaks }=\frac{\text { Jumlah dari } T \text { max } \text { harian dalam satu bulan }}{\text { Jumlah hari dalam satu bulan }} \\
& \text { Tmin }=\frac{\text { Jumlah dari } T \text { min } \text { harian dalam satu bulan }}{\text { Jumlah hari dalam satu bulan }} \\
& \text { Tmean }=\frac{\text { Tmax }+ \text { Tmin }}{2}
\end{aligned}
$$

Dalam proses ini, Tsiang dan Tmalam pada LST MODIS, dianalogikan sama dengan Tmaks dan Tmin pada pengukuran $\mathrm{T}$ stasiun. Sementara, panjang hari/lama 
penyinaran (p) ditentukan berdasarkan posisi lintang, dan didapatkan berdasarkan ketentuan FAO (Tabel 2).

Tabel 2. Rata-rata persentase harian dari jam siang hari tahunan untuk berbagai lintang menurut FAO (FAO, 1986)

\begin{tabular}{|c|c|c|c|c|c|c|c|c|c|c|c|c|c|}
\hline \multirow{2}{*}{ Latitude } & North & Jan & Feb & Mar & Apr & May & June & July & Aug & Sept & Oct & Nov & Dec \\
\hline & South & July & Aug & Sept & Oct & Nov & Dec & Jan & Feb & Mar & Apr & May & June \\
\hline $60^{\prime}$ & 15 & 20 & 26 & 32 & 38 & 41 & 40 & 34 & 28 & 22 & 17 & 13 \\
\hline $55^{\prime}$ & 17 & 21 & 26 & 32 & 36 & 39 & 38 & 33 & 28 & 23 & 18 & 16 \\
\hline $50^{\prime}$ & 19 & 23 & 27 & 31 & 34 & 36 & 35 & 32 & 28 & 24 & 20 & 18 \\
\hline $45^{\prime}$ & 20 & 23 & 27 & 30 & 34 & 35 & 34 & 32 & 28 & 24 & 21 & 20 \\
\hline $40^{\prime}$ & 22 & 24 & 27 & 30 & 34 & 34 & 33 & 31 & 28 & 25 & 22 & 21 \\
\hline $35^{\prime}$ & 23 & 25 & 27 & 29 & 32 & 32 & 32 & 30 & 28 & 25 & 23 & 22 \\
\hline $30^{\prime}$ & 24 & 25 & 27 & 29 & 31 & 32 & 31 & 30 & 28 & 26 & 24 & 23 \\
\hline 25 & 24 & 26 & 27 & 29 & 31 & 31 & 31 & 29 & 28 & 26 & 25 & 24 \\
\hline $20^{\prime}$ & 25 & 26 & 27 & 28 & 30 & 30 & 30 & 29 & 28 & 26 & 25 & 25 \\
\hline $15^{\prime}$ & 26 & 26 & 27 & 28 & 29 & 29 & 29 & 28 & 28 & 27 & 26 & 25 \\
\hline $10^{\prime}$ & 26 & 27 & 27 & 28 & 29 & 29 & 29 & 28 & 28 & 27 & 26 & 26 \\
\hline 5 & 27 & 27 & 27 & 28 & 28 & 28 & 28 & 28 & 28 & 27 & 27 & 27 \\
\hline $0^{\prime}$ & 27 & 27 & 27 & 27 & 27 & 27 & 27 & 27 & 27 & 27 & 27 & 27 \\
\hline
\end{tabular}

Setelah nilai Tmean dan nilai $\mathrm{P}$ didapatkan, selanjutnya, dilakukan perhitungan Evapotranspirasi Potensial (ETo) menurut persamaan Blaney-Criddle. (Doorenbos dan Pruitt, 1977):

$$
\text { Eto }=\mathrm{p}(0.46 \text { Tmean }+8.13)
$$

Kemudian, dilakukan perbaikan data evapotranspirasi yang dihasilkan berdasarkan perhitungan LST MODIS, untuk mengisi piksel-piksel yang mengandung cukup banyak 'missing data'. Dalam hal ini, dilakukan kombinasi data 8 harian selama satu bulan (Tsiang dan Tmalam) dengan memilih kombinasi data LST yang memiliki ketersediaan data lebih lengkap secara spasial, sehingga dalam satu bulan, data dapat direkonstruksikan dari kombinasi 2 sampai 4 data observasi 8 harian. Selanjutnya, nilai evapotranspirasi kembali dihitung dengan menggunakan rumus BlaneyCriddle. Validasi data dilakukan untuk mengetahui nilai $\mathrm{R}^{2}$ dan hubungan data sebelum dan sesudah perbaikan.

\section{HASIL DAN PEMBAHASAN}

\section{Validasi Data LST MODIS Tahun 2011 dan Data T Stasiun Klimatologi pada Berbagai Ketinggian dan Waktu}

Validasi data MODIS dilakukan pada LST siang dan LST malam untuk mendapatkan hubungan nilai LST terhadap ketinggian sangkar meteo. Pada tahap ini, Tmaks dan Tmin stasiun dianalogikan sama dengan nilai LST siang dan LST malam sesuai saran dari Maeda et al. (2011) dan Vancutsem et al. (2010).

Berdasarkan Gambar 1, terlihat bahwa LST MODIS siang memiliki hubungan yang cukup dekat dengan T stasiun iklim (staklim) pada ketinggian $5 \mathrm{~cm}$ dan $100 \mathrm{~cm}$. Walaupun demikian, terlihat bahwa pada bulan dan hari tertentu, terdapat penyimpangan yang cukup jauh antara LST MODIS dengan T stasiun.

Perbandingan nilai LST MODIS malam memberikan interaksi yang berbeda dengan apa yang ditunjukkan pada validasi data LST MODIS siang. Pada validasi LST MODIS malam, terlihat bahwa nilai LST
MODIS malam memiliki hubungan yang cukup dekat dengan data $\mathrm{T}$ stasiun $120 \mathrm{~cm}$. Walaupun demikian, fluktuasi temperatur pada LST MODIS malam masih terlihat. Analisis korelasi antara LST siang (Gambar 2) dan $\mathrm{T}_{5}$, menghasilkan nilai $\mathrm{R}^{2}$ terbesar, yaitu 0.36 jika dibandingkan dengan kedua nilai lainnya (0.30 untuk LST siang dan $\mathrm{T}_{100} ; 0.28$ untuk LST siang dan $\mathrm{T}_{120}$. Namun demikian, pada LST malam (Gambar 2), nilai $\mathrm{R}^{2}$ tertinggi justru didapatkan pada hubungan antara LST malam dengan $\mathrm{T}_{100}$, dengan nilai $\mathrm{R}^{2}$ sebesar 0.57 dan bukan pada LST malam dan $\mathrm{T}_{120}\left(0.44\right.$ untuk LST malam dan $\mathrm{T}_{5} ; 0.28$ untuk LST malam dan $\mathrm{T}_{120}$ ).

Dugaan sementara akan adanya perbedaan nilai interaksi ketinggian pada LST MODIS siang dan LST MODIS malam adalah akibat perbedaan waktu akuisisi data dan pengambilan data T stasiun. Pada LST MODIS malam, pengambilan data dilakukan pada pukul 22.30 waktu lokal solar. Sementara, pada T stasiun, pengambilan data dilakukan pada pukul 07.00 WIB. Sehingga, nilai Tmin yang dimaksud pada LST MODIS malam, menjadi terlihat lebih setara dengan pengukuran $\mathrm{T}$ stasiun pada ketinggian $120 \mathrm{~cm}$. Sementara itu, fluktuasi LST MODIS yang terdapat pada LST siang dan LST malam lebih dipengaruhi oleh faktor iklim dan cuaca. Fluktuasi tersebut menyebabkan nilai $\mathrm{R}^{2}$ menjadi lebih kecil.

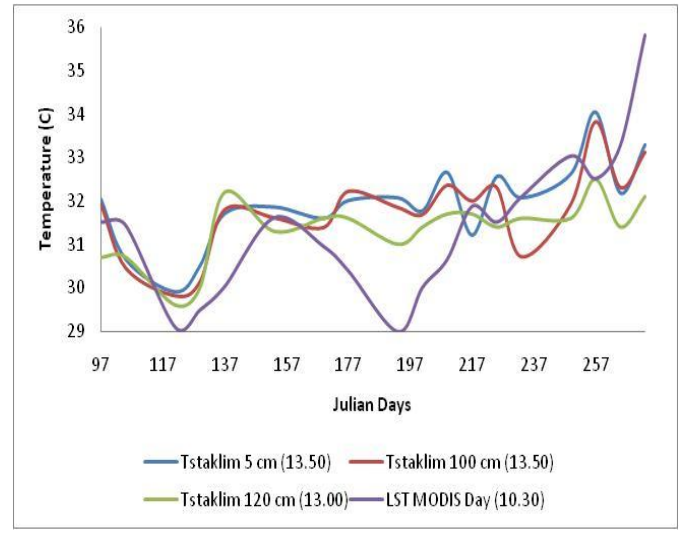

a). LST siang-Tstaklim

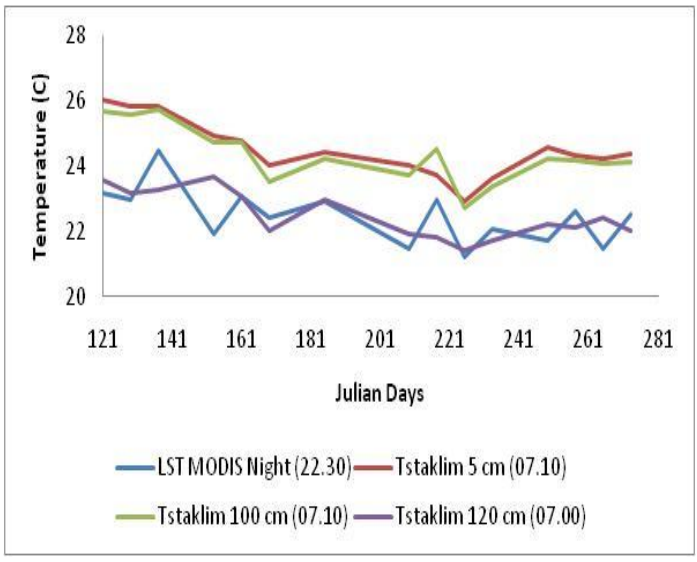

b). LST malam-Tstaklim

Gambar 1. Perbandingan LST MODIS siang dan malam dengan temperatur stasiun klimatologi Dramaga, Bogor (Tahun 2011) pada berbagai ketinggian 


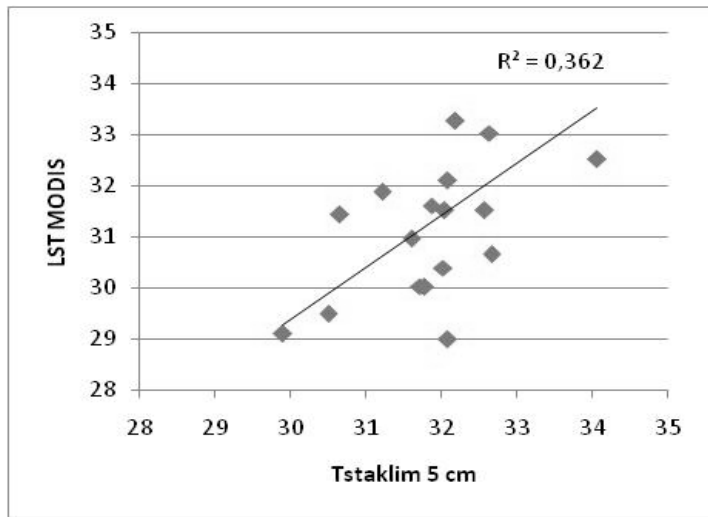

a). LSTsiang- $\mathrm{T}_{5}$

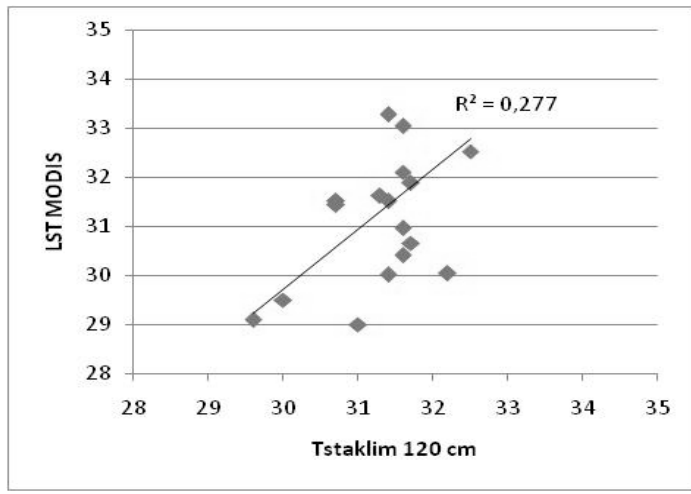

c). LSTsiang- $\mathrm{T}_{120}$

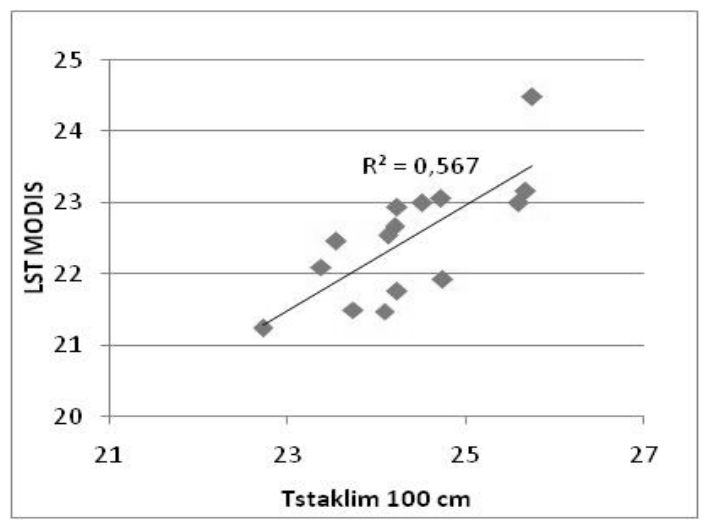

e). LSTmalam-T 100

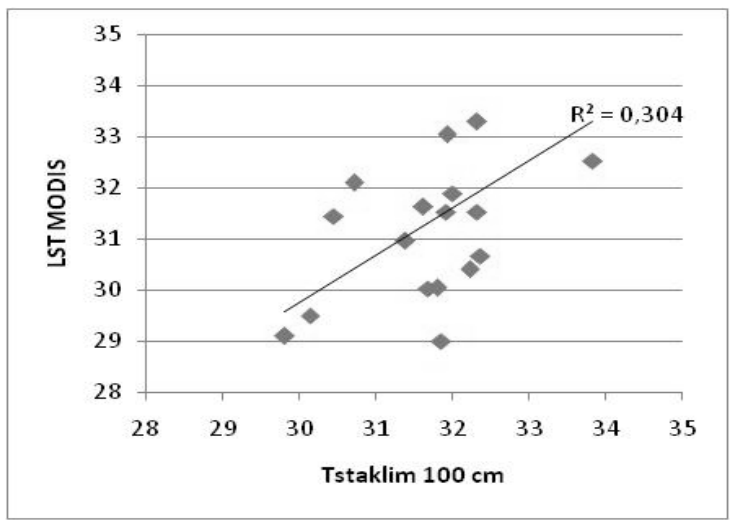

b). LSTsiang- $\mathrm{T}_{100}$

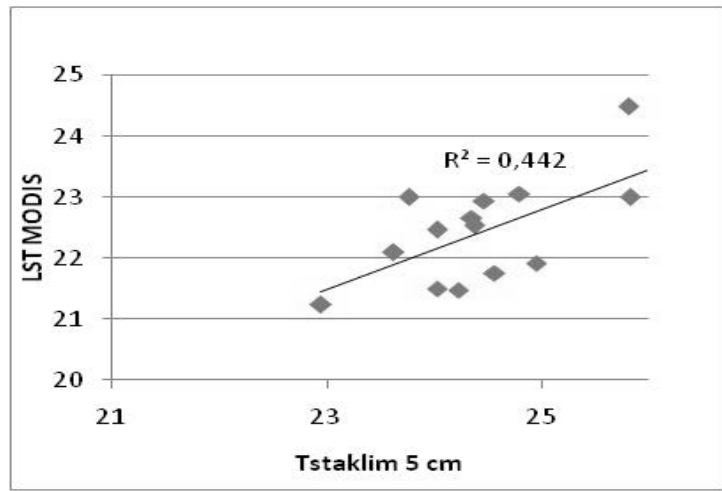

d). LSTmalam-T 5

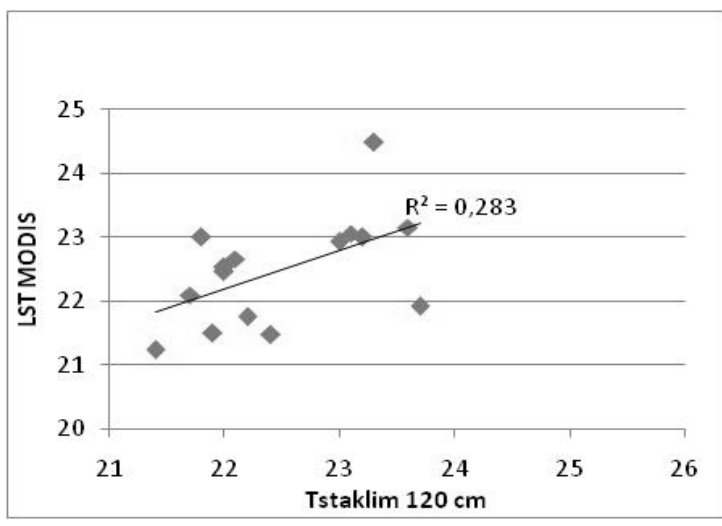

f). $L S T m a l a m-T_{120}$

Gambar 2. Nilai $\mathrm{R}^{2}$ antara LST MODIS dan T stasiun pada berbagai ketinggian

\section{Perhitungan Evapotranspirasi dengan Metode Blaney- Criddle}

Hasil perhitungan evapotranspirasi potensial dengan menggunakan metode Blaney-Criddle sejak bulan April hingga Oktober disajikan secara spasial dan temporal pada Gambar 3. Sementara, pada awal bulan (JanuariMaret) dan akhir bulan (November-Desember), ketersediaan data mencapai $0 \%$. Hal tersebut diduga akibat faktor anomali iklim, yaitu fenomena La Nina yang diketahui cukup dominan pada tahun 2009-2010. Secara umum, Gambar 3 menunjukkan bahwa dengan menggunakan basis data penginderaan jauh, distribusi evapotranspirasi suatu wilayah dapat diketahui, baik secara spasial maupun temporal.

Analisis hubungan antara evapotranspirasi potensial dengan topografi dan penggunaan lahan pada
Gambar 4a menunjukkan bahwa distribusi evapotranspirasi pada DAS Cimadur cenderung mengikuti bentuk topografi wilayahnya. Nilai evapotranspirasi cenderung tinggi pada wilayah bagian selatan dan semakin menurun ke arah utara. Di bagian tengah (utara), cenderung kembali meningkat akibat terdapat suatu cekungan pada wilayah tersebut.

Gambar 4c menunjukkan hubungan antara elevasi dengan nilai ET pada berbagai penggunaan lahan. Dengan menganalogikan bahwa besarnya evapotranspirasi berbanding lurus dengan suhu, maka pada gambar tersebut terlihat bahwa sensor MODIS memiliki sensitifitas terhadap suhu, berdasarkan jenis vegetasi dan ketinggian. Gambar 4c (A, B, C, G; dan D, E, F) menunjukkan bahwa dengan vegetasi yang sama, nilai suhu yang ditangkap MODIS, akan berbeda pada ketinggian yang berbeda. 

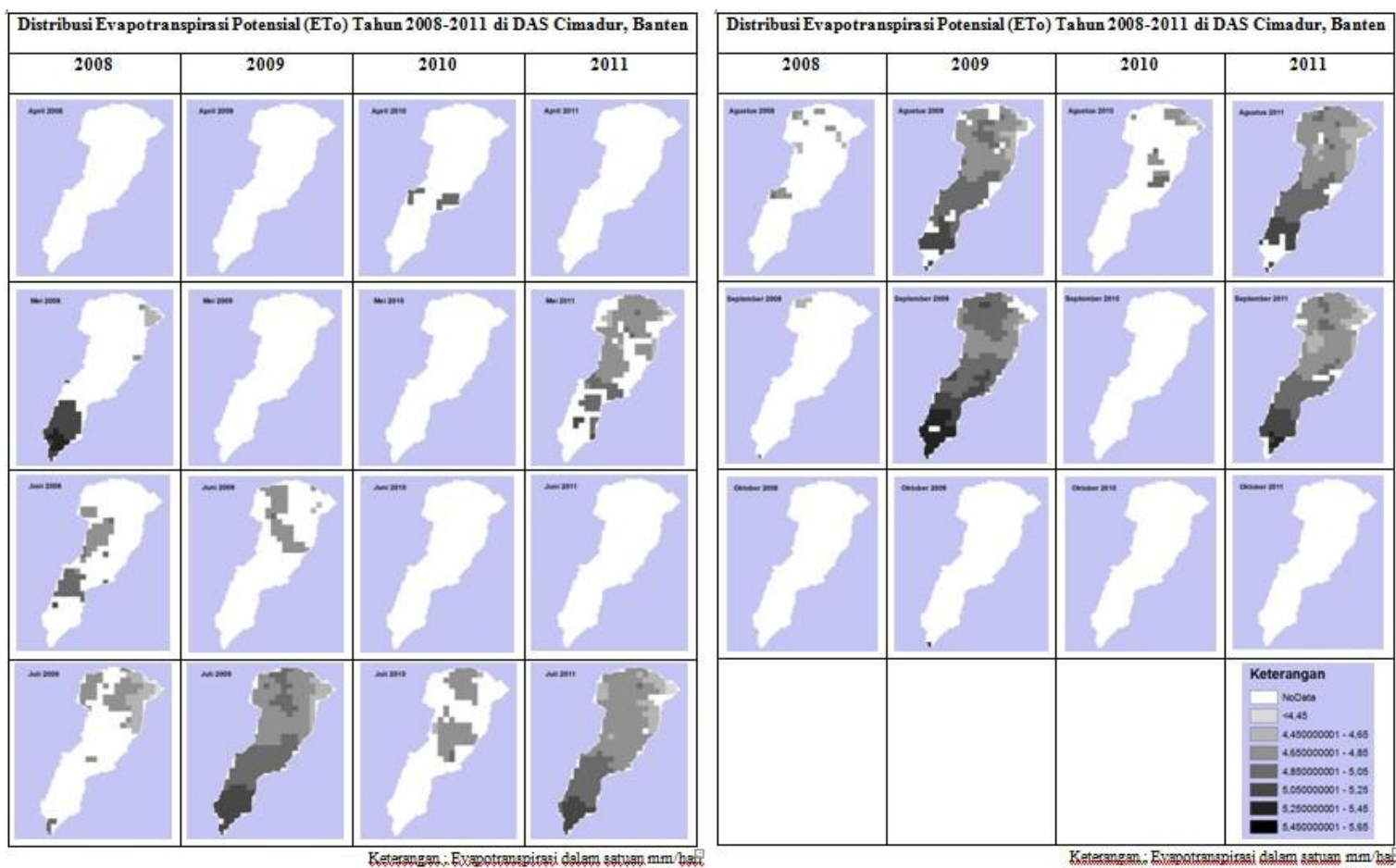

Gambar 3. Distribusi evapotranspirasi potensial secara spasial dan temporal pada tahun 2008-2011

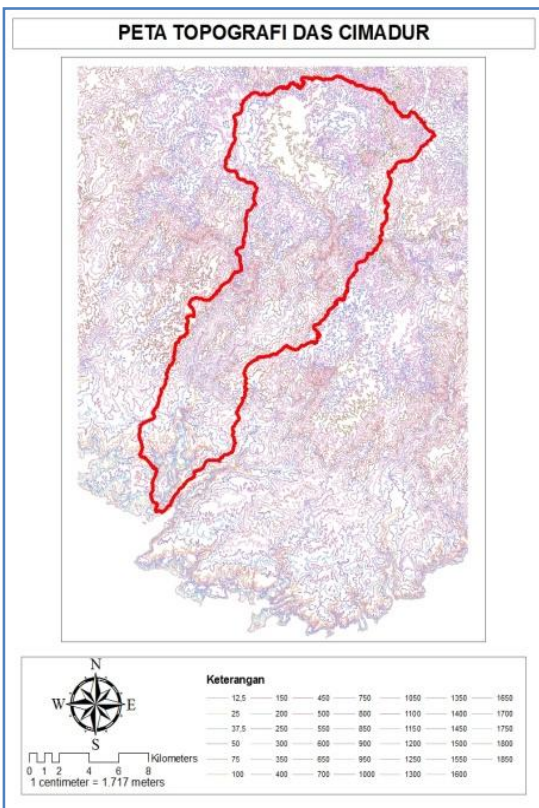

(a)

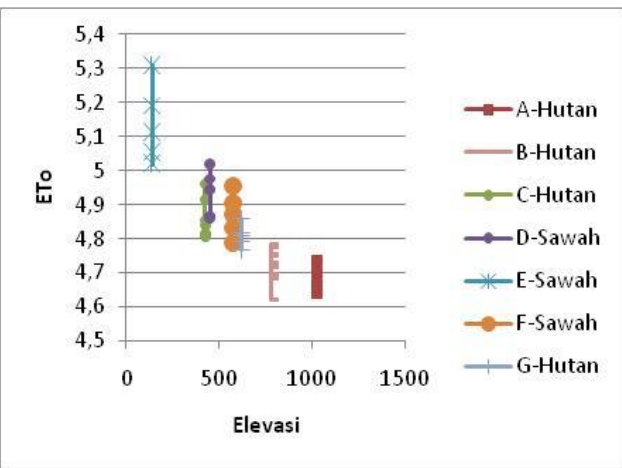

(c)

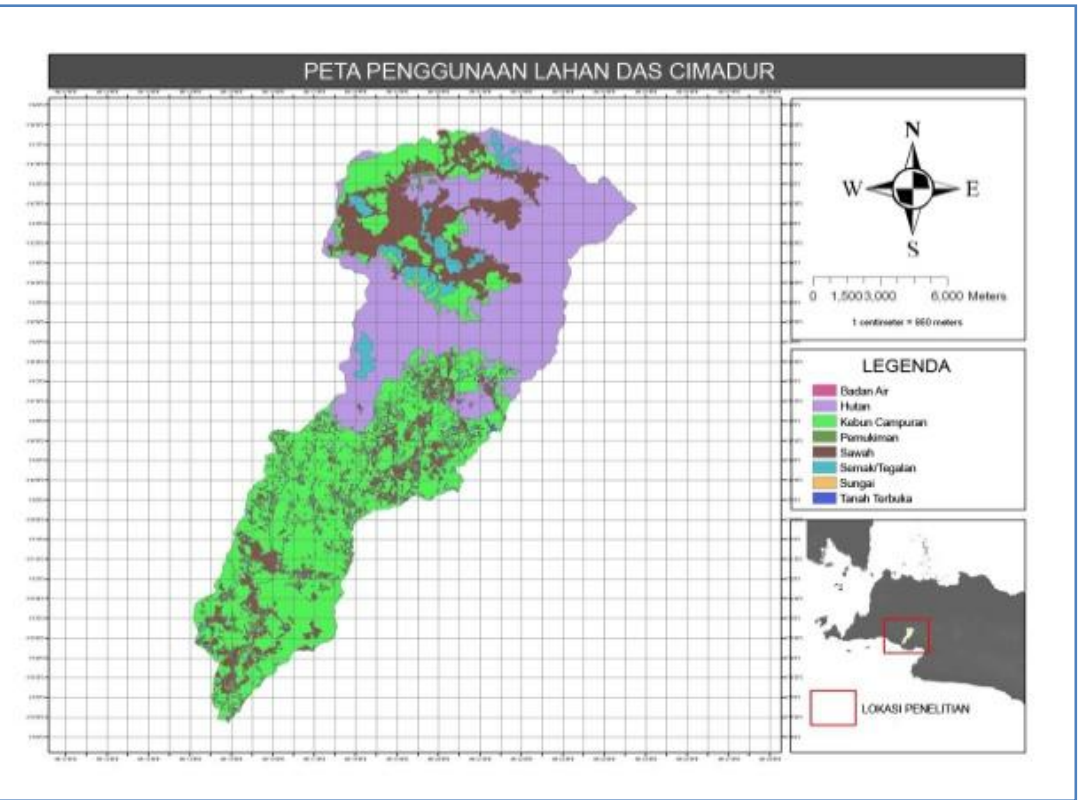

(b)

Gambar 4. Hubungan antara nilai ET, topografi, dan penggunaan lahan: (a) peta topografi DAS Cimadur; (b) peta penggunaan lahan DAS Cimadur; (c) grafik hubungan elevasi dengan nilai ET 


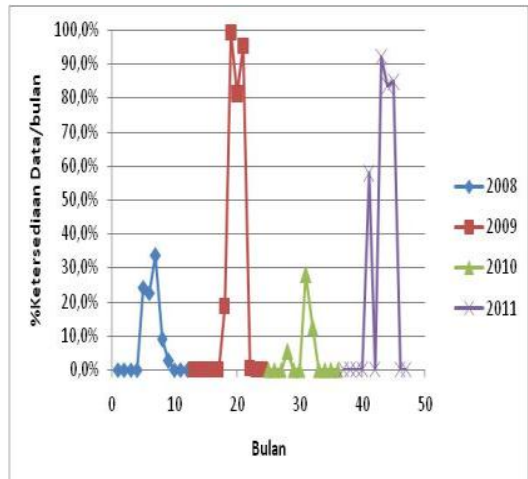

(a)

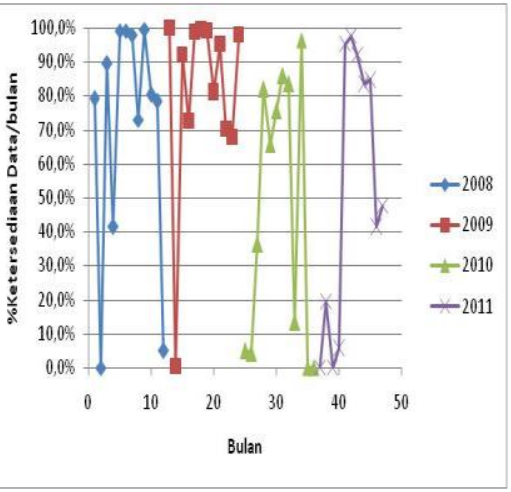

(b)

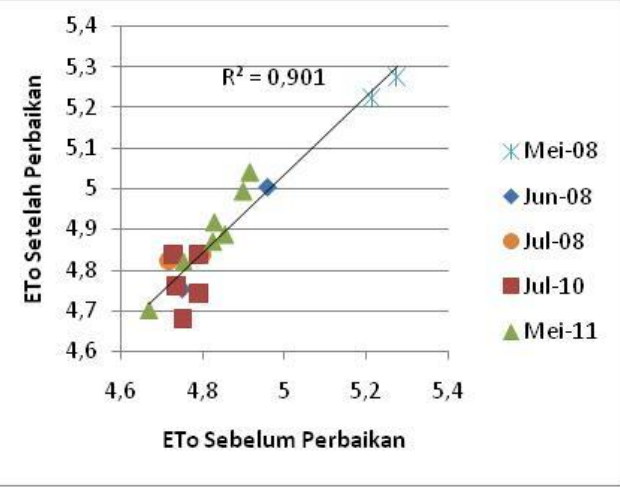

(c)

Gambar 5. Grafik pengaruh perbaikan data Trata-rata terhadap data evapotranspirasi potensial: (a) sebelum perbaikan; (b) setelah perbaikan; (c) nilai $\mathrm{R}^{2}$ perbandingan hasil analisis ETo sebelum dan sesudah perbaikan data

\section{Pengaruh Perbaikan Data Trata-rata (Tsiang dan Tmalam) terhadap Ketersediaan Data Evapotranspirasi Potensial secara Spasial dan Temporal}

Perbaikan data evapotranspirasi potensial dilakukan dengan mengkombinasikan data 8 harian terbaik pada data Tsiang dan Tmalam pada LST MODIS, sehingga akan memberikan perbaikan terhadap data $\mathrm{T}$ ratarata yang digunakan dalam persamaan Blaney-Criddle. Berdasarkan hasil perbaikan data LST MODIS, secara umum data Tsiang lebih tersedia dibandingkan Tmalam. Selain itu, kombinasi-kombinasi data dalam proses perbaikan, semakin memperkuat dugaan bahwa data LST MODIS tersedia secara baik pada musim kemarau atau saat kondisi cuaca baik (tidak hujan). Penelitian ini juga mengindikasikan bahwa pada wilayah tropika basah, penguatan ketersediaan data dengan teknik agregasi data antar waktu (multitemporal composite) yang umum dilakukan oleh penyedia data belum tentu dapat menyelesaikan permasalahan liputan awan yang sangat tinggi.

Hasil perbaikan menunjukkan bahwa pada tahun 2008, ketersediaan data meningkat dari 5 bulan data tersedia menjadi 11 bulan data tersedia. Tahun 2009, ketersediaan data meningkat dari 5 bulan data tersedia menjadi 12 bulan data tersedia. Tahun 2010, ketersediaan data meningkat dari 3 bulan data tersedia menjadi 10 bulan data tersedia. Sedangkan pada tahun 2011, ketersediaan data meningkat dari 4 bulan data tersedia menjadi 9 bulan data tersedia. Sementara, dengan dilakukannya perbaikkan, ketersediaan data dalam satu bulan, dapat meningkat lebih dari $50 \%$ dari kondisi awalnya $0 \%$. Selain itu, hasil analisis korelasi antara hasil perhitungan ETo sebelum dan sesudah perbaikan data, menunjukan nilai $\mathrm{R}^{2}$ sebesar 0.90 (Gambar 5). Artinya, proses perbaikkan data tidak merubah secara signifikan nilai ETo yang dihasilkan dari perbaikkan data tersebut, apabila dibandingkan dengan nilai ETo sebelum perbaikkan data.

\section{SIMPULAN}

1. Pada validasi data LST MODIS dengan data T stasiun, didapatkan bahwa nilai LST siang MODIS lebih mendekati pengukuran temperatur stasiun iklim pada ketinggian $5 \mathrm{~cm}$ (apabila dibandingkan dengan pengukuran temperatur pada ketinggian lainnya) dengan nilai $\mathrm{R}^{2}$ sebesar 0.36 , sedangkan LST malam, memiliki hubungan yang cukup kuat dengan $\mathrm{T}$ stasiun pada ketinggian $120 \mathrm{~cm}$. Namun demikian, nilai $\mathrm{R}^{2}$ tertinggi diperoleh pada hubungan antara LST malam dengan $\mathrm{T}$ stasiun pada ketinggian $100 \mathrm{~cm}$, dengan nilai $\mathrm{R}^{2}$ sebesar 0.57 . Perbedaan tersebut disebabkan oleh fluktuasi cuaca/iklim, dan juga perbedaan waktu akuisisi data MODIS.

2. Kajian mengenai pengembangan perhitungan evapotranspirasi dengan menggunakan data LST MODIS sebagai penduga suhu, memberikan rentang nilai evapotranspirasi sebesar 4.45-5.65 mm hari ${ }^{-1}$ pada wilayah penelitian. Pengembangan perhitungan ini sekaligus menyajikan pola penyebaran evapotranspirasi secara spasial dan temporal.

3. Sebagai salah satu masukan pada perhitungan evapotranspirasi, LST MODIS memberikan ketersediaan data yang baik pada musim-musim kering/musim kemarau, dan pada kondisi cuaca baik (tidak hujan atau berawan). Penelitian ini juga membuktikan bahwa tidak semua bulan dalam satu tahun memiliki ketersediaan data MODIS yang diharapkan.

4. Distribusi evapotranspirasi secara temporal sepanjang tahun agak sulit untuk dilakukan mengingat ketersediaan data MODIS yang cukup minim. Namun demikian, secara spasial terlihat bahwa nilai evapotranspirasi pada penelitian ini memiliki ketergantungan yang tinggi terhadap suhu. Sementara itu, suhu yang diestimasi oleh LST MODIS, erat kaitannya dengan topografi dan penggunaan lahan di suatu wilayah.

\section{DAFTARPUSTAKA}

Asdak, C. 2010. Hidrologi dan Pengelolaan Daerah Aliran Sungai. Yogyakarta: Gajah Mada University Press.

Doorenbos, J. and W.O. Pruitt. 1977. Guidelines for Predicting Crop Water Requirements. FAO 
Irrigation and Drainage Paper. No 56. Rome: FAO.

FAO. 1986. Irrigation Water Management: Irrigation Water Needs.

www.fao.org/docrep/S2022E/s2022e07.htm\#3.3 $\% 20$ calculation $\% 20$ of $\% 20$ the $\% 20$ crop $\% 20$ watr $\%$ 20need. (diakses pada 2 Desember 2011).

Maeda, E.E., D.A. Wiberg, and P.K.E. Pellikka. 2011. Estimating reference evapotranspiration using remote sensing and empirical models in a region with limited ground data availability in Kenya. Applied Geography, 31:251-258.

Tomlinson, C.J., L. Chapman, J.E. Thornes, and C. Baker. 2011. Remote sensing land surface temperature for meteorology and climatology: a review. Meteorological Applications, 18:296-306.
Vancutsem C., P. Ceccato, T. Dinku, and S.J. Connor. 2010. Evaluation of MODIS land surface temperature data to estimate air temperature in different ecosystem over Africa. Remote Sensing of Environment, 114:449-465.

Wang, Y., S. Traore, and T. Kerh. 2007. Determination of a reference model for estimating evapotranspiration in Burkina Faso. Proceedings of the 6th WSEAS Int. Conf. On Artificial Intelligence, Knowledge Engineering and data Bases, Corfu Island, Greece. 